\title{
Ocular diseases in dogs naturally affected by visceral leishmaniasis in Teresina, Piauí, Brazil
}

\author{
Marcus Valérius de Matos Freitas ${ }^{1}$ Cristiane Ferreira da Luz Brun ,6* $^{*}$ \\ Marcelo Campos Rodrigues ${ }^{3}$ Georgia Brenda Barros Alves ${ }^{4}$ Ariane Farias Leal ${ }^{5}$ \\ Esther Machado de Carvalho e Silva ${ }^{4}$ Lucas Grolli $^{6}$ Ana Maria Quessada ${ }^{2}$
}

\begin{abstract}
${ }^{1}$ Programa de Pós-graduação em Ciência Animal, Universidade Federal do Piauí (UFPI), Teresina, PI, Brasil.
${ }^{2}$ Programa de Pós-graduação em Ciência Animal, Universidade Paranaense (UNIPAR), Umuarama, PR, Brasil.

${ }^{3}$ Centro de Ciências da Saúde, Departamento de Biofísica e Fisiologia, Universidade Federal do Piauí (UFPI), Teresina, PI, Brasil.

${ }^{4}$ Médica Veterinária autônoma, Teresina, PI, Brasil.

${ }^{5}$ Programa de Pós-graduação em Medicina Tropical e Doenças Internacionais, Instituto de Medicina Tropical, Universidade de São Paulo (USP), São Paulo, SP, Brasil.

${ }^{6}$ Curso de Medicina Veterinária, Faculdades de Itapiranga (FAI), 89896-000, Itapiranga, SC, Brasil. E-mail: crisflbrun@yahoo.com.br. ${ }^{*}$ Corresponding author.
\end{abstract}

ABSTRACT: This study aimed to characterize ocular diseases in dogs naturally affected by visceral leishmaniasis in Teresina, Piaui State, Brazil. The diagnosis was made using parasitological exams of the bone-marrow and lymph-node samples. The main ophthalmological findings were uveitis, conjunctivitis, blepharitis, keratitis, and keratoconjunctivitis sicca. Normocytic normochromic anemia was the main hematological finding, followed by thrombocytopenia. Plasma proteins were also considered, and hyperproteinemia, hypergammaglobulinemia, and hypoalbuminemia were observed. Ocular histopathological examination revealed mild inflammation involving lymphocytes, monocytes, and macrophages. Results indicate the need to perform a differential diagnosis to rule out or establish the presence of Leishmania sp. in dogs presenting with ophthalmic lesions in endemic regions.

Key words: canine, eye, Leishmania sp, zoonosis.

Oftalmopatias em cães naturalmente acometidos por leishmaniose visceral em Teresina, PI, Brasil

Resumo: O presente trabalho teve por objetivo caracterizar as oftalmopatias em cães naturalmente afetados por leishmaniose visceral em Teresina, Piauí. O diagnóstico de leishmaniose foi realizado por exame parasitológico de medula óssea e linfonodos. As principais alterações oftálmicas foram uveite, conjuntivite, blefarite, ceratite e ceratoconjuntivite seca. Anemia normocitica normocrômica foi a principal alteração hematológica, seguida de trombocitopenia. Em relação às proteinas plasmáticas observou-se hiperproteinemia, hiperglobulinemia e hipoalbuminemia. A histopatologia ocular revelou processo inflamatório moderado constituído por linfócitos, monócitos, neutrófilos e macrófagos. Os resultados da pesquisa apontam para a necessidade de se realizar diagnóstico diferencial para Leishmania sp. em cães que apresentem lesões oftálmicas em regiões endêmicas.

Palavras-chave: canino, Leishmania sp, olho, zoonose.

\section{INTRODUCTION}

Visceral leishmaniasis (VL) is a chronic systemic disease that affects both dogs and humans (TORRES et al., 2006). Several Leishmania species have been found to affect dogs in South America; however, in Brazil, the most frequent etiological agent of the disease is Leishmania infantum chagasi (DANTA-TORRES, 2009), a protozoan of the family Trypanosomatidae (NOLI, 1999).
The main vector for this parasite is the Phlebotominae insect Lutzomyia longipalpis; however, there is evidence of Leishmania sp. Being transmitted by Lutzomyia cruzi in Brazil (PIRAJÁ \& LUCHEIS, 2014). The domestic dog (Canis familiaris) is considered the main reservoir host for leishmaniasis in Brazil (LEITE et al., 2010).

Ocular manifestations in canine visceral leishmaniasis (CVL) are associated with other systemic findings of this disease (ROZE, 2005). 
Studies show that the prevalence of ocular diseases in dogs affected by VL varies from $25 \%$ to $80 \%$ (CIARAMELLA et al., 1997; KOUTINA, et al., 1999). Ocular symptoms in dogs with leishmaniasis may range from simple conjunctivitis to severe cases of panophthalmitis (PEÑA et al., 2000).

Given the absence of studies describing ophthalmological findings observed clinically in dogs with CVL and the scarcity of studies on histopathological changes in the ocular structures of dogs suffering from CVL in Brazil, the objective of this study is to describe the ophthalmic lesions in cases of CVL and to characterize the histopathological changes in different ocular structures.

\section{MATERIALS AND METHODS}

The study population consisted of a random selection of 100 male and female dogs $>3$ months of age. A total of 18 dogs were selected from private veterinary clinics located in the city of Teresina (Piauí State, Brazil), whereas 55 dogs were selected from the veterinary hospital of Universidade Federal do Piauí (Piauí State, Brazil), and 27 dogs were selected from the Department of Zoonosis Management of Teresina (GEZON), also located in Piauí State, Brazil. All of the dogs had tested positive for CVL. This study was approved by the Ethics Committee on Animal Experimentation of the Universidade Federal do Piauí (case number 071/12).

All dogs underwent a parasitological examination to detect any amastigote forms of Leishmania sp. in the bone-marrow and lymph-node samples. The bone-marrow samples were obtained from the sternum or tibial crest using $40 \times 12-\mathrm{mm}$ needles and 20-mL syringes, whereas samples from the popliteal or prescapular lymph nodes were obtained using $25 \times 8$ $\mathrm{mm}$ needles and $10-\mathrm{mL}$ syringes. Immediately after each collection, smears were made on microscope slides using the squash smear technique. The samples were fixed in methanol and stained according to the Romanowsky technique (Giemsa). The diagnosis was CVL-positive when Leishmania amastigote forms were found on the slides.

Complete blood count and albumin, globulin, alanine aminotransferase (ALT), urea, and creatinine tests were determined for all of the animals.

Eight dogs infected with Leishmania sp. and severe clinical findings were euthanized. Their eyes were fixed in $10 \%$ buffered formalin, processed, and included in paraffin. To search for inflammation processes and amastigote forms of the parasite, these organs were cut into $5-\mu \mathrm{m}$ slices and stained with hematoxylin and eosin (HE).
The eye examination assessed the eyelids, palpebral and bulbar conjunctivae, third eyelid, cornea, sclera, anterior chamber, iris, and pupil with the aid of a halogen light and a magnifying glass that provided $2.5 \times$ magnification. Whenever possible, the crystalline lens, vitreous humor, retina, and optic nerve were assessed by direct ophthalmoscopy. A mydriatic eye drop (Mydriacyl, 1\% tropicamide, Alcon, Brazil) was used for the fundoscopy.

Tear production was assessed using Schirmer tear flow strips (Ophthalmos, Brazil) whereas intraocular pressure was assessed using a rebound tonometer. The presence of corneal lesions and the extent of lacrimal drainage (Jones test) were determined with the aid of fluorescein dye on dried strips (Ophthalmos, Brazil) dissolved in $1 \mathrm{~mL}$ of physiological saline.

\section{RESULTS AND DISCUSSION}

Of the total number of dogs (100), 46 were male and 54 were female. Only the dogs from veterinary clinics and the HVU (73) had their ages recorded, and their ages ranged from 4 months to 12 years. Most of the dogs studied were of an unknown breed, but several breeds were reported (Table 1). These data suggest that leishmaniasis has no predilection for any age nor breed in the endemic area studied herein. Other studies have reported similar findings (ALMEIDA et al., 2010; SEIXAS et al., 2012). Although some authors state that this disease is more common in males (SEIXAS et al., 2012), the current study found showed no predilection for one sex over another, nor did another study (ALMEIDA et al., 2010). This difference may be related to sampling. The first study used 23 animals, whereas our study used 100 animals.

Of the 100 dogs assessed, 73\% (73/100) were found to have a monoinfection by Leishmania sp. The others showed coinfection with Ehrlichia canis. We only included the dogs with monoinfection in the clinical and histopathological study. It is important to note that infections were detected using cytopathological examination (presence of amastigotes) in the lymphnode and bone-marrow samples.

Although dogs with VL may remain asymptomatic, this study was similar to others (ALMEIDA et al., 2010) in its finding of a higher prevalence of symptomatic dogs among those monoinfected by Leishmania sp. (74.5\%; 54/73). The major clinical findings observed in the monoinfected and symptomatic dogs in this study were ocular lesions $(92 \% ; 50 / 54)$, skin diseases $(82 \% ; 44 / 54)$, adenomegaly $(75 \% ; 41 / 54)$, onychogryphosis $(74 \% ; 40 / 54)$, and weight loss $(38 \%$; 20/54) (Figure 1). Other authors mention clinical findings 
Table 1 - Number and percentage of dogs that underwent cytopathological examination of the bone-marrow and lymph-node samples to search for amastigote forms of Leishmania spp. $(\mathrm{n}=100)$ in Teresina (Piauí State, Brazil) according to breed.

\begin{tabular}{lcc}
\hline Breeds & Number & Percentage (\%) \\
\hline Unknown breed & 37 & 37 \\
Poodle & 25 & 25 \\
Pit bull & 10 & 10 \\
Pinscher & 6 & 6 \\
Shar-pei & 3 & 3 \\
German shepherd & 3 & 3 \\
Rottweiler & 3 & 3 \\
Beagle & 2 & 11 \\
Other known breeds (one individual each) & 11 & 11 \\
Total & 100 & 100 \\
\hline
\end{tabular}

similar to those observed in this study (ALMEIDA et al., 2010). These findings reflect the systemic nature of this disease in dogs (CIARAMELLA et al., 1997).

In another study (ROZE, 2005), 38\%

VL-infected dogs presented only ocular lesions. In the current study, only $4 \%$ animals $(2 / 54)$ had ocular lesions. The other dogs presented ocular findings associated with other clinical issues, as observed in another study (ALMEIDA et al., 2010). Once again, these findings represent the systemic nature of the

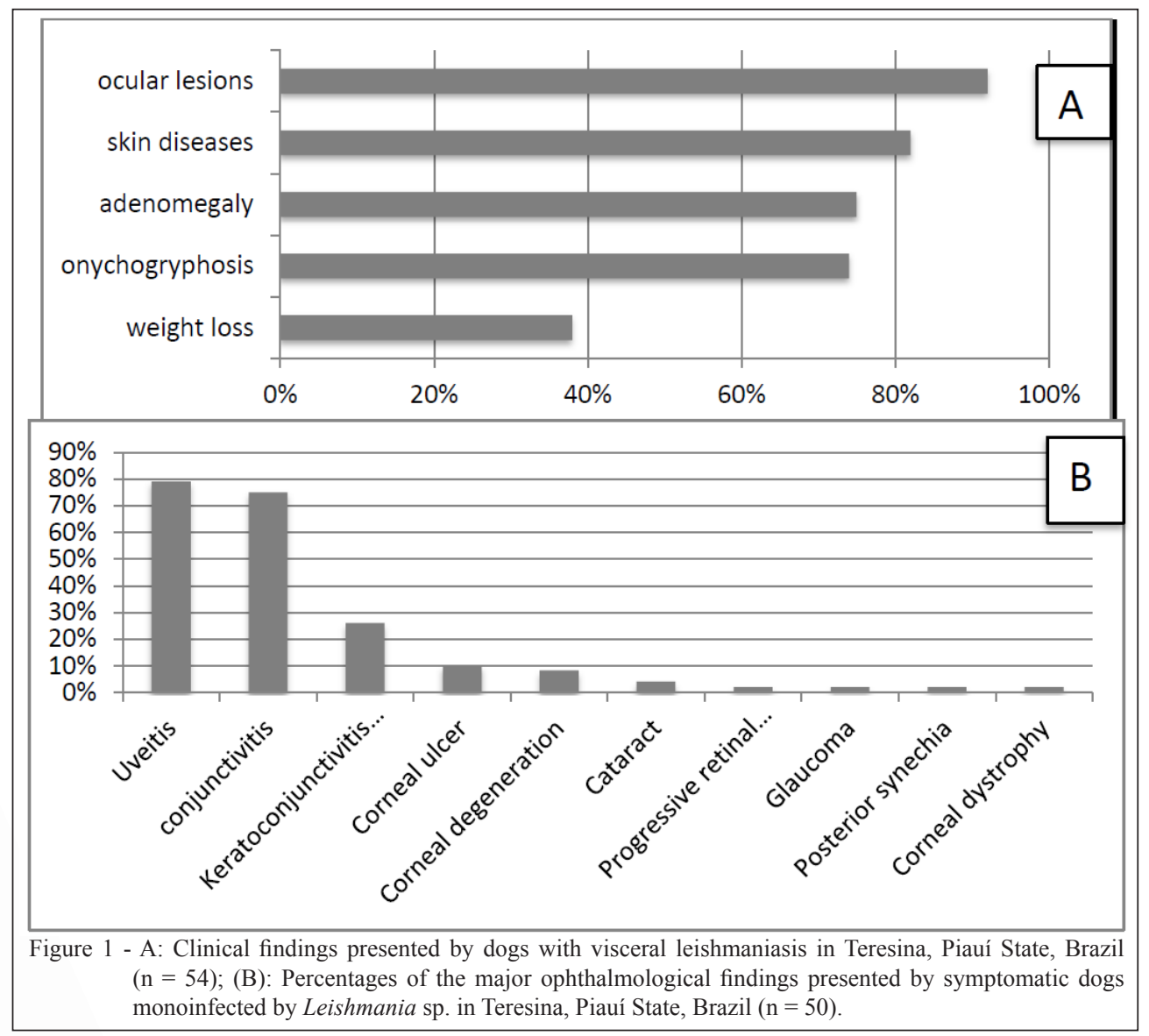

Ciência Rural, v.47, n.10, 2017. 
disease (CIARAMELLA et al., 1997). Nevertheless, ocular findings are relevant for this disease in dogs and can aid in the diagnosis (SILVA et al., 2017).

Normocytic normochromic anemia was the most prevalent hematological alteration, affecting $82.6 \%(60 / 73)$ dogs. Anemia is a frequent clinical sign in CVL (IKEDA et al., 2003; FREITAS et al., 2012; BRAZ et al., 2015). It is usually attributed to blood loss (epistaxis and melena), hemolysis (production of autoantibodies, immune complexes, and erythrocyte membrane instability), or decreased erythropoiesis (inflammatory disease anemia, iron deficiency, chronic kidney disease, and erythrocyte dysplasia) (IKEDA et al., 2003; FREITAS et al., 2012).

Platelet counts reflected thrombocytopenia in $40.6 \%$ (29/73) of the dogs assessed, and thrombocytosis was found in only $3 \%$ samples (2/73). Thrombocytopenia is frequent in cases of CVL (FREITAS et al., 2012; BRAZ et al., 2015), and it can be explained by vasculitis resulting from immune complex deposits (BUSH, 2004), changes in platelet production, increased platelet destruction, and presence of antiplatelet antibodies (TERRAZANO et al., 2006).

Increased urea occurred in $18.4 \%$ dogs $(13 / 73)$, and increased creatinine was found in $9.5 \%(7 / 73)$. These findings are common in cases of CVL and suggest kidney damage (FREITAS et al., 2012). Kidney failure is a common cause of death in leishmaniasis (TORRES et al., 2013).

Protein electrophoresis showed that $82 \%$ dogs (60/73) presented high levels of total proteins; globulin fraction was increased in $92 \%$ dogs studied herein (67/73). Albumin values were below reference values in $88 \%$ cases $(64 / 73)$. Protein electrophoresis also revealed albumin/globulin ratios below $1.5 \mathrm{mg} /$ $\mathrm{dL}$ in $99 \%$ samples analyzed (72/73). Other authors mention these same abnormalities in dogs with VL (IKEDA et al., 2003; FREITAS et al., 2012; BRAZ et al., 2015). Hyperproteinemia in CVL occurs as a result of the polyclonal activation of B cells, which increases antibody production ( $\gamma$-globulin) (IKEDA et al., 2003).

We observed ophthalmological findings in 92.0\% symptomatic dogs assessed (50/54) (Figure 1); of these, $98.6 \%(49 / 50)$ presented them bilaterally. Bilateral ocular lesions are a common finding in cases of CVL (PEÑA et al., 2000; NARANJO et al., 2005; PEÑA et al., 2008) and may be associated with its chronicity (BRITO et al., 2006) and with the systemic nature of the disease (CIARAMELLA et al., 1997).

As in another study (BRITO et al., 2006), anterior uveitis was the most prevalent ophthalmological findings. It was found in 79\% dogs $(39 / 50)$, and nearly all of the cases were bilateral $(95 \% ; 47 / 50)$ (Figure 1).
Other diseases can cause uveitis in dogs, including those of idiopathic origin (immunomediated), neoplasia, trauma, hypermature cataracts, ehrlichiosis, and other infectious causes (MASSA et al., 2002). However, the animals considered in this study tested negative for Erlichia sp., which was therefore not a possible cause for uveitis. However, infection by Erlichia sp. is one of the most frequent causes of uveitis in Brazil (PINTO \& CARVALHO, 2013). The animals did not show clinical findings of other diseases that could cause this issue.

Anterior uveitis, as other ocular changes observed in dogs with leishmaniasis, occurs largely because of vasculitis, which itself results from the deposition of circulating immune complexes on vessel walls (BRITO et al., 2010). Hence, uveitis in dogs with VL has an immunological source (PEÑA et al., 2000).

One of the consequences of uveitis is the formation of posterior synechiae, which was found in one dog in this study. These synechiae were probably to the result of the direct action of amastigote forms of the parasite or of the deposition of immune complexes on the anterior uvea (BRITO et al., 2010).

All cases of uveitis in this study occurred only in the anterior segment of the eye. These findings are probably to the result of the fact that anterior uveitis precedes posterior uveitis (COLLINS and MOORE, 1991). In addition, fundoscopic examination is not always possible in dogs with CVL (PEÑA et al., 2000; BRITO et al., 2006) because of difficulties such as insufficient pupil response to mydriatics and deficient intraocular media transparency (FULGÊNCIO, 2006). We encountered these difficulties in the ophthalmological examination of the dogs studied herein, a factor which may justify the absence of the diagnosis of uveitis in the posterior segment. It is important to note that we found no inflammatory process of the posterior segment in any of the 16 eyes (eight dogs) that underwent histopathological examinations. However, dogs with VL may present lesions in the posterior segment, such as chorioretinitis and retinal detachment (CIARAMELLA et al., 1997; PEÑA et al., 2000; BRITO et al., 2010) as a result of the expansion of the inflammatory processes from the anterior segment (COLLINS and MOORE, 1991).

A very frequent clinical ophthalmological finding was conjunctivitis (Figure 1), which was observed in $75.0 \%$ symptomatic dogs (40/54), and it was bilateral in $100 \%$ cases. CVL conjunctivitis occurs mainly as a result of the deposition of circulating immune complexes, which triggers vasculitis (BRITO et al., 2010). Another mechanism that may be involved in its development is the direct action of the parasite upon the conjunctiva (FULGÊNCIO, 2006; BRITO et al., 2010). 
Among the changes to the cornea observed herein, keratoconjunctivitis sicca (KCS) was diagnosed in $26.0 \%(14 / 54)$ of the symptomatic dogs assessed (Figures 1 and 2). This finding is in accordance with the literature, which indicates that the prevalence of KCS in dogs with VL can range from $2.6 \%$ to $26.8 \%$ (KOMNENOU and KOUTINAS, 2007). Decreased aqueous fraction of tears was associated with the presence of other clinical findings of the disease, such as ocular discharge, corneal edema, pigmentation and vascularization of the cornea, conjunctivitis, and keratitis (COLLINS and MOORE, 1991). A study on the lacrimal glands of canines with VL sought to determine the pathogenic mechanisms of KCS and found granulomatous infiltrate around the lacrimal gland ducts with consequent retrograde dilation and accumulation of secretions because of the presence of Leishmania amastigotes, culminating in the development of KCS (NARANJO et al., 2005). Thus, the likely etiology of $\mathrm{KCS}$ in the dogs studied herein may be the obstruction

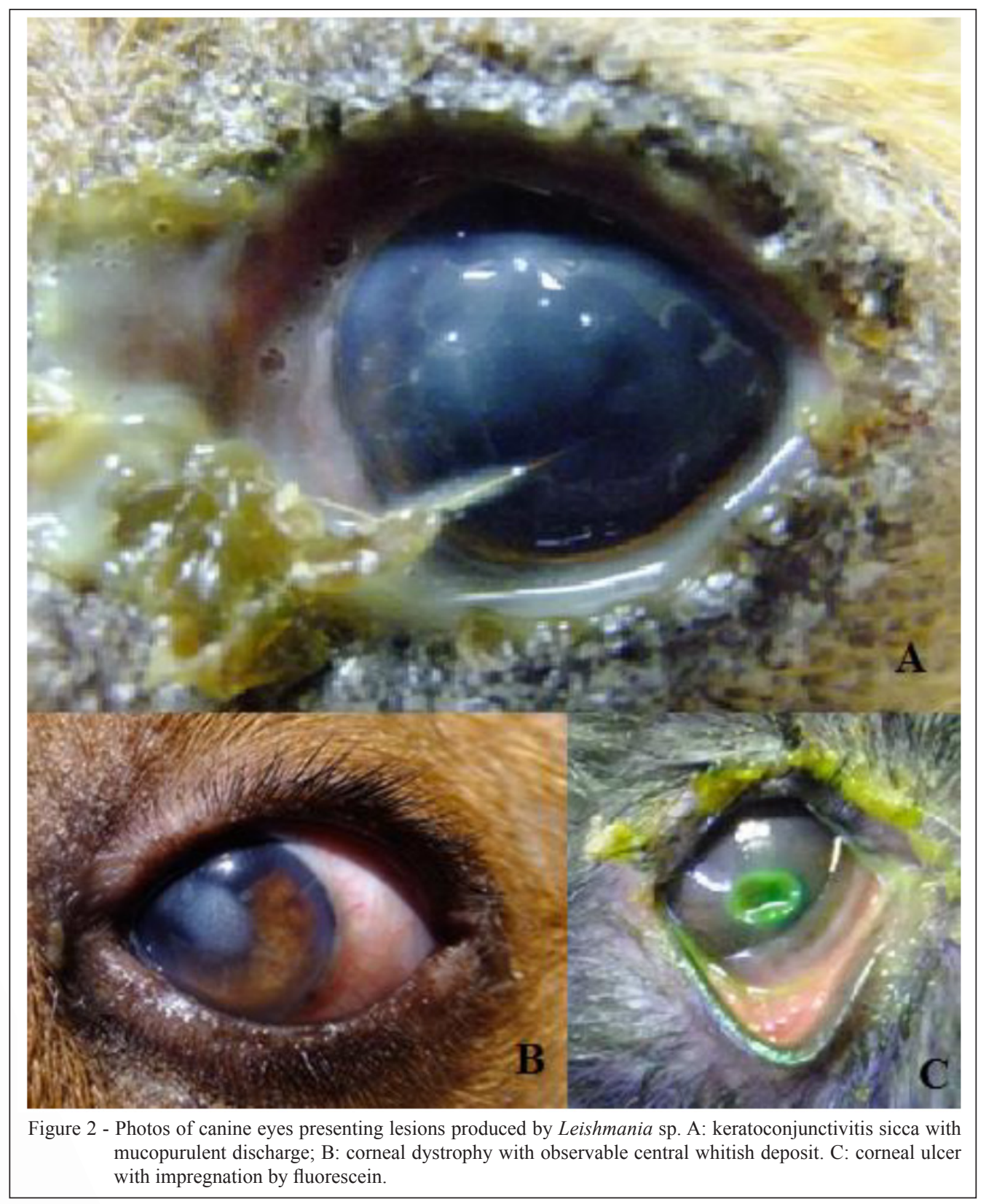

Ciência Rural, v.47, n.10, 2017. 
of the tear ducts caused by adjacent inflammatory processes (FULGÊNCIO, 2006).

Another frequent observation (71\%; $52 / 73$ of the dogs) was the negative fluorescein result when assessing the patency of the nasolacrimal drainage (Jones test). This finding suggests the presence of dacryocystitis, a finding not reported in other studies.

We found unilateral corneal deposits associated with inflammation and vascularization of the cornea and compatible with corneal degeneration in $8.2 \%$ dogs studied (6/73). Corneal degeneration is a rare ocular disease in dogs with VL; they may have kidney disease associated with uremia, a condition which can explain this type of deposit in the cornea (FULGÊNCIO, 2006).

One dog presented bilateral central corneal deposits not associated with an inflammatory process and suggestive of corneal dystrophy (Figure 2). Although rare, this can occur in cases of CVL (ROZE, 2005). However, it is unlikely that the corneal dystrophy observed in this study is associated with the presence of Leishmania sp., because this type of deposit is hereditary in nature and has no concomitant inflammatory process (HERRERA, 2008).

One dog presented progressive retinal atrophy. This ocular lesion can occur in dogs with VL (PEÑA et al., 2008) and likely arises from the deposition of immune complexes (BRITO et al., 2010).

Glaucoma was diagnosed in one dog, as in other studies with dogs with LV PEÑA et al., 2000). It was likely secondary to anterior uveitis, given the presence of inflammatory cells in the structures that make up the drainage angle of the aqueous humor (PEÑA et al., 2008).

Cataracts were diagnosed in $4 \%$ cases $(2 / 50)$

(Figure 1). Although no correlation has been established between the formation of cataracts and leishmaniasis, it is worth considering that changes in the aqueous humor in dogs with VL and uveitis can make the crystalline lens opaque (FULGÊNCIO, 2006).

We observed corneal ulcers (Figures 1 and 2) in $10 \%$ dogs $(5 / 50)$. These lesions are unusual clinical findings in CVL, but when they are present, they are associated with inflammatory process produced by the presence of amastigotes in the cornea (BRITO et al., 2007).

Of the 16 eyes evaluated by histopathological examination, $87.5 \%(14 / 16)$ presented inflammatory infiltrates, with an intensity ranging from discreet to severe, and with focal and multifocal distribution (Figure 3A). When the ocular structures were considered, we found abnormalities in the anterior uveal tract. In the ciliary body, there was abundance of inflammatory infiltrates in the lymphocytes, plasma cells, and macrophages invading the loose connective tissue and smooth muscles and beginning around a vessel, findings which represent perivasculitis (Figure 3B). These results are similar to those reported by other authors who have studied the same disease in dogs (PEÑA et al., 2008; BRITO et al., 2010). Inflammatory lesions characterized by mononuclear inflammatory infiltrates have been observed in histopathological studies of leishmaniasis, but other studies have not reported the presence of the amastigote form of Leishmania found herein (KLOTZ et al., 2000).

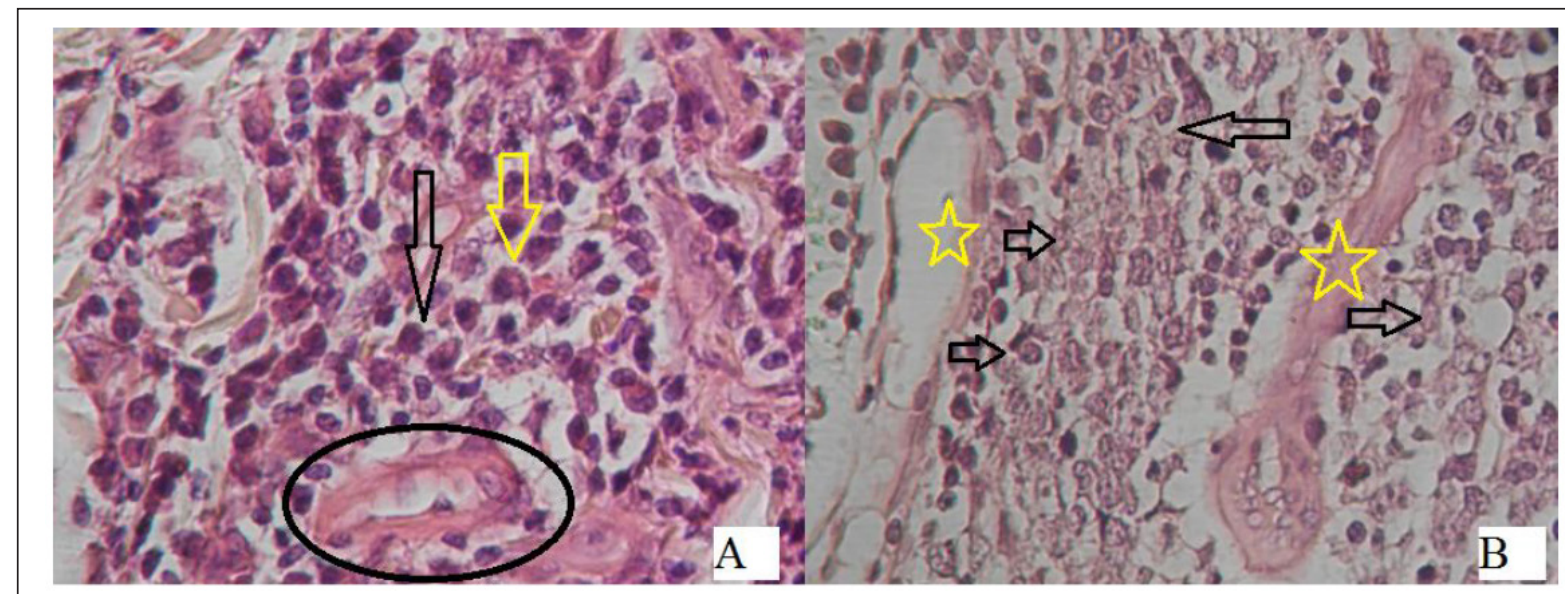

Figure 3 - Histopathological examination of eyes of dogs monoinfected by Leishmania sp. Histopathological section stained with HE; $40 \times$ magnification. A: Anterior uveal tract, ciliary body presenting abundant mononuclear perivascular inflammatory infiltrate (Circle: vessel; black arrow: lymphoplasmacytic infiltrate; yellow arrow: macrophages). B: Lymphoplasmacytic perivascular inflammatory infiltrate (stars: vessels; arrows: inflammatory infiltrate). 


\section{CONCLUSION}

Ocular lesions were common clinical findings in dogs with CVL in Teresina, Piauí State, Brazil, and were found at a prevalence of $92 \%$ in monoinfected dogs. These issues can occur in isolation (as the only sign of the disease) or can be associated with other, more classic findings of the disease. Anterior uveitis represents the primary ocular issue associated with VL and may trigger secondary glaucoma and iris synechiae. The presence of inflammatory processes in ocular structures may suggest a direct action of the parasite in the pathogenesis of ophthalmic lesions of immunomediated nature in the inflammatory response. Thus, VL should be included in the differential diagnosis of ophthalmic lesions in dogs by clinicians and pathologists, especially in endemic areas.

\section{REFERENCES}

ALMEIDA, A.B.P.F. et al. Prevalência e epidemiologia da leishmaniose visceral em cães e humanos, na cidade de Cuiabá, Mato Grosso, Brasil. Ciência Rural, v.40, n.7, p.1610-1615, 2010. Available from: $<$ http://dx.doi. org/10.1590/S0103-84782010005000102>. Accessed: Jun. 06, 2016.

BRAZ, P.H. et al. Perfil hematológico de cães naturalmente infectados por leishmania spp. Acta Veterinária Brasílica, v.9, n.1, p.87-90, 2015. Available from: $<\mathrm{http} / / \mathrm{dx}$.doi.org/10.21708/avb.2015.9.1.5273>. Accessed: set. 15, 2016.

BRITO, F.L.C. et al., Ocular alterations in dogs naturally infected by Leishmania (Leishmania) chagasi. Arquivo Brasieiro de Medicina Veterinária e Zootecnia, v. 58, n.5, p.768-775, 2006. Available from: $<$ http://dx.doi.org/10.1590/S0102-09352006000500011>. Accessed: nov. 20, 2016.

BRITO, F.L.C. et al. Amastigotas forms resembling Leishmania sp. On corneal ulceration in dog: case report. Arquivo Brasieiro de Medicina Veterinária e Zootecnia, v.59, n.1., p.81-84, 2007. Available from: $<$ http://dx.doi.org/10.1590/S0102-09352007000100014>. Accessed: ago. 06, 2016.

BRITO, F.L.C. et al. Histopathological findings and detection of parasites in the eyes of dogs infected naturally with Leishmania chagasi. Ciência Rural, v. 40, n. 5, p. 1141-1147, 2010. Available from: <http://dx.doi. org/10.1590/S0103-84782010005000079>. Accessed: set.15, 2016.

BUSH, B.M. Interpretação de Resultados Laboratoriais para Clínicos de Pequenos Animais. São Paulo: Roca, 2004. 376p.

CIARAMELLA, P. et al. A retrospective clinical study of canine leishmaniasis in 150 dogs naturally infected by Leishmania infantum. Veterinary Record, v. 141, n. 22, p. 539-543, 1997. Available from: $<\mathrm{http}$ ://dx.doi.org/10.1136/vr.141.21.539>. Accessed: nov.20, 2016.

COLLINS, B.K.; MOORE, C.P. Canine anterior uvea. In: GELATT, K.N. Veterinary Ophthalmology. 2.e.Philadelphia: Wiliams \& Wilkins, 1991, p.357-395. Cap.10.

DANTAS-TORRES, F. Canine leishmaniosis in South America Parasites \& Vectors, v.2 (supl. 1), 2009. Available from: <https:// doi.org/10.1186/1756-3305-2-S1-S1>. Accessed: Set. 15, 2016.
FREITAS, J.C.C. et al., Clinical and laboratory alterations in dogs naturally infected by Leishmania chagasi. Revista da Sociedade Brasileira de Medicina Tropical, v.45, n.1, p.24-29, 2012. Available from: $<$ http://dx.doi. org/10.1590/S0037-86822012000100006>. Accessed: Ago. 14, 2016.

FULGÊNCIO, G.O. Prevalência de oftalmopatias em cães naturalmente infectados com Leishmania (Leishmania) chagasi no município de Belo Horizonte-MG. 2006. 48p. Dissertação (Mestrado em Ciência Animal) - Escola de Veterinária, Universidade Federal de Minas Gerais, Belo Horizonte, 2006.

HERRERA, D.H. Oftalmologia Clínica em Animais de Companhia. São Paulo: MedVet, 2008. 300p.

IKEDA, F.A. et al. Perfil hematológico de cães naturalmente infectados por Leishmania chagasi no município de Araçatuba, São Paulo: estudo retrospectivo de 191 casos. Clínica Veterinária, v.8, n. 47, p. 42-47, 2003

KLOTZ, S.A. et al. Fungal and Parasitic Infections of the Eye. Clinical microbiology reviews, v.13, n.4, p. 662-685, 2000. Available from: < http://cmr.asm.org/content/13/4/662>. Accessed: set. 26, 2016. doi: 10.1128/CMR.13.4.662-685.2000.

KOMNENOI, A.; KOUTINAS, A.F. Ocular manifestations of some canine infectious and parasitic diseases commonly encountered in the Mediterranean. European Journal of Companion Animal Practice, v. 17, n. 3, p. 271-279, 2007.

KOUTINAS, A.F. et al. Clinical considerations on canine visceral leishmaniasis in Greece: a retrospective study of 158 cases (1989-1996). Journal of American Animal Hospital Association, v. 35, n.5, p.376-383, 1999. Available from: <https://doi.org/10.5326/15473317-35-5-376>

LEITE, R.S. et al., PCR diagnosis of visceral leishmaniasis in asymptomatic dogs using conjunctival swab samples. Veterinary Parasitology, v. 170, n.3-4, p. 201-206, 2010. Available from: $<$ http:// dx.doi.org/10.1016/j.vetpar.2010.02.020>. Accessed: Ago. 19, 2016.

MASSA, KL. et al. Causes of uveitis in dogs: 102 cases (1989-2000). Veterinary Ophthalmology, v.5, n.2, p.93-98, 2002. Available from: <https://www.ncbi.nlm.nih.gov/pubmed/12071865>. Acessed: Accessed: Jul. 10, 2016. doi: 10.1046/j.1463-5224.2002.00217.x.

NARANJO, C. et al., Characterization of lacrimal gland lesions and possible pathogenic mechanisms of keratoconjunctivitis sicca in dogs with leishmaniosis. Veterinary Parasitology, v.133, n.1, p. 37-47, 2005. Available from: $<$ https://doi.org/10.1016/j.vetpar.2005.05.017>. Accessed: Mai. 17, 2016

NOLI, C. Canine leishmaniasis. Waltham Focus, v.9, n.2, p.1624, 1999.

PEÑA, M.T. etal. Ocular and periocular manifestations of leishmaniasis in dog: 105 cases (1993-1998). Veterinary Ophthalmology, v.3, n.1, p.35-41, 2000. Available from: <https://www.ncbi.nlm.nih.gov/ pubmed/11397281>. Accessed: Ago. 19, 2016. doi: 10.1046/j.14635224.2000.00106.x

PEÑA, M. T. etal., Histopathological Features of Ocular Leishmaniasis in the dog. Journal of Comparative Pathology, v. 138, n. 1, p. 32-39, 2008. Available from: <https://doi.org/10.1016/j.jcpa.2007.09.004>. Accessed. Set. 27, 2016.

PINTO, A.B.T.; CARVALHO, C.B. Oftalmopatias na erliquiose monocítica canina. Jornal Brasileiro de Ciência Animal, v.6, n.12, 
p. 442-452, 2013. Available from: <http://www.jbca.com.br/v6n12/ material_dez_2013/3oftalmopatias_na_erliquiose_canina.pdf $>$. Accessed: Set. 27, 2016.

PIRAJÁ, G.V.; LUCHEIS, S.B. A vigilância epidemiológica de flebotomíneos no planejamento de ações de controle nas leishmanioses. Veterinária e Zootecnia, v.21, n.4, p. 50-53, 2014. Available from: $<$ http://www.fmvz.unesp.br/rvz/index.php/rvz/article/view/703>.

PONTES, K.C.S.; VIANA, J.A.; DUARTE, T.S. Etiopatogenia da uveíte associada a doenças infecciosas em pequenos animais. Revista Ceres, v.53, n.310, p.531-539, 2006. Available from: <http://www. redalyc.org/articulo.oa>. Accessed. Out. 10, 2016.

ROZE, M. Canine leishmaniasis. A spreading disease. Diagnosis and treatment. European Journal of Companion Animal Practice, v. 15 , n.1, p. 39-52, 2005.

SEIXAS, M.M. et al., Positividade para leishmaniose visceral canina: existem fatores caninos que contribuem? Revista Baiana de Saúde Pública, v. 36, n. 2, p. 358, 2013. Available from: <http://bases. bireme.br/cgibin/wxislind.exe/iah/online/?IsisScript=iah/iah.
SILVA, K.R. et al., Scoring clinical signs can help diagnose canine visceral leishmaniasis in a highly endemic area in Brazil. Memórias do Instituto Oswaldo Cruz, v.112, n.1, p. 53-62, 2017. Available from: <http://dx.doi.org/10.1590/0074-02760160305>. Accessed: Mai. 08, 2016.

TERRAZANO, G. et al., Presence of anti-platelet IgM and IgG antibodies in dogs naturally infected by Leishmania infantum. Veterinary Immunology and Immunopathology, v. 110, n. 3-4, p. 331-337, 2006. Available from: $<$ https://doi.org/10.1016/j.vetimm.2005.11.001>. Accessed. Nov.18, 2016.

TORRES, F.P.; BRITO, M.E.F., FILHO, S.P.B., Seroepidemiological survey on canine leishmaniasis among dogs from an urban area of Brazil. Veterinary Parasitology, v. 140, n. 1-2, p. 54-60, 2006. Available from: <https://doi.org/10.1016/j.vetpar.2006.03.008>. Accessed: Nov.03,2016.

TORRES, M.M. et al. Associação da carga parasitária renal com achados laboratoriais em cães com leishmaniose visceral. Ciência Rural, v.43, n.5, p.894-896, 2013. Available from: <http://dx.doi.org/10.1590/S0103-84782013005000032>. Accessed: Jul. 25, 2016. 